\title{
Artigo
}

\section{A linguagem e a agenda: uma análise de correspondência de discursos relacionados à Emenda da Reeleição (1995-1997)}

\author{
Parlance and agenda: a correspondence analysis \\ of speeches related to the Reelection Amendment \\ (1995-1997)
}

\author{
Victor Garcia Miranda \\ Professor Adjunto, Universidade Federal de Mato Grosso do Sul \\ (UFMS), Campo Grande, MS, Brasil \\ miranda.victorg@gmail.com
}

\begin{abstract}
Resumo: $O$ presente trabalho corresponde a um estudo empírico descritivo e exploratório que aborda comportamentos e falas de atores políticos que participaram do processo legislativo de aprovação da Emenda da Reeleição por meio de instrumento metodológico conhecido como Análise de Correspondência. Para tanto, busca-se a solução da seguinte questão: com que frequência e de que modo estiveram associadas as posições políticas e as opiniões discursivas de quem esteve envolvido no processo de aprovação da Emenda da Reeleição? Os dados utilizados foram discursos que fizeram menção à Emenda da Reeleição encontrados nas colunas Painel da Folha de S. Paulo e nos resumos de pronunciamentos proferidos por deputados federais e senadores nos diários oficiais da Câmara dos Deputados, do Senado Federal e do Congresso Nacional. Separou-se o referido material entre discursos exógenos e endógenos relativos ao tema, e analisou-se 1) a frequência da associação textual dos termos-chave e 2) a correspondência correlacional entre eles - houve inserção do material coletado em um software de análise estatística, o Iramuteq. Os resultados indicaram que uma manifestação retórica articulada a uma série de expressões léxicas capazes de revelar o que da agenda de governo de FHC era associado à aprovação da referida emenda constitucional. A principal característica do processo político em questão foi ser uma especialidade sistêmica de algo que era o elemento basilar da agenda de reformas de FHC I: a estabilização monetária brasileira advinda do Plano Real. A Emenda da Reeleição "pegou carona" deliberadamente no Plano Real, conforme constatado na associação retórica empiricamente analisada por este trabalho.
\end{abstract}

Palavras-chave: Emenda da reeleição; Reformas constitucionais; Análise lexicológica; Agenda de governo. 


\begin{abstract}
The present work corresponds to a descriptive and exploratory empirical study that approaches behaviors and speeches of political actors who participated in the approval legislative process of the Reelection Amendment through a methodological instrument known as Correspondence Analysis. To that end, the following question is sought: how often and in what way were the political positions and discursive opinions associated with those involved in the approval process of the Reelection Amendment? The data used were speeches that made mention to the Amendment of Reelection found in the Folha de S. Paulo Panel columns and in the summaries of pronouncements issued by federal deputies and senators in the official diaries of the Chamber of Deputies, the Federal Senate and the National Congress. The material was separated in exogenous and endogenous speeches related to the theme, and it was analyzed 1) the frequency of the textual association of the key terms and 2) the correlation between them - there was insertion of the material collected in statistical analysis software, the Iramuteq. The results indicated that a rhetorical manifestation articulated to a series of lexical expressions capable of revealing what of the FHC government agenda was associated with the approval of the referred constitutional amendment. The main characteristic of the political process in question was to be a systemic specialty of something that was the basilar element of the FHCI reform agenda: the Brazilian monetary stabilization coming from the Real Plan. The Reelection Amendment deliberately "took a ride" on the Real Plan, as evidenced by the rhetorical association empirically analyzed by this work.
\end{abstract}

Keywords: Reelection amendment; Constitutional reforms; Lexicological analysis; Government agenda.

\title{
Introdução
}

Entrevistador - O senhor, que defendeu que o arrecadado com as privatizações fosse empregado em investimentos sociais, sentiu-se derrotado pelos economistas do governo quando o Presidente anunciou que o dinheiro será usado para pagar a dívida pública?

Motta - Não. No discurso, o Presidente disse que o dinheiro será usado para manter a estabilidade econômica. Que essa é a sua obsessão, e não será mudada num ano eleitoral. Concordo integralmente com essa visão. (MOTTA, 1997).

O excerto acima pode ser considerado sintomático da essência de uma retórica que tende a associar aspectos de decisão política à situação econômica do país. Em plena corrida política para se defender das denúncias jornalísticas em que era classificado como mandante de operação de compra de votos para aprovação da Emenda da Reeleição' na Câmara dos Deputados, o ministro Sérgio Motta admite que os recursos

1 Refere-se à Emenda da Reeleição a dinâmica política manifesta em torno da Proposta de Emenda à Constituição (PEC) que tratava da inserção do instituto de direito eleitoral à reeleição imediata para detentores de mandatos no Poder Executivo brasileiro. Intitulada PEC 01/1995 na Câmara dos Deputados - posteriormente, PEC 04/1997 no Senado Federal, em termos estritamente procedimentais do processo legislativo em si, pode-se dizer que a Emenda da Reeleição foi a mudança constitucional que possibilitou a reeleição de prefeitos municipais, governadores estaduais e do Presidente da República foi apresentada na 50a legislatura do Congresso Nacional e tornou-se o Decreto Legislativo de Emenda Constitucional n. ${ }^{16 / 1997}$, publicado pela mesa diretora do Congresso no dia 04/06/1997. Por efeito das muitas exigências formais e 
T\&P A linguagem e a agenda: uma análise de correspondência de discursos relacionados à Emenda da Reeleição (1995-1997)

arrecadados nos processos de privatização de estatais pelo primeiro governo de Fernando Henrique Cardoso (1995-1998) deveriam ser utilizados para a estabilização monetária. Demonstrando anuência para com aquilo que considera a "obsessão" do presidente da república, Motta singelamente admite concordância em relação aos planos de FHC. Aplicando interpretação de silogismo à situação, é possível considerar que aquele que "concorda integralmente com essa visão" (Motta) seria capaz também de fazer o possível para que a Emenda da Reeleição fosse aprovada no Congresso, caso ela estivesse explicitamente atrelada ao projeto de estabilidade econômica de FHC.

O presente trabalho corresponde a um estudo empírico descritivo de caráter exploratório sobre comportamentos e falas de atores políticos que participaram do processo legislativo de aprovação da Emenda da Reeleição. Para tanto, busca-se a solução da seguinte questão: com que frequência e de que modo estiveram associados conteúdos políticos e econômicos nas posições políticas e as opiniões discursivas de quem esteve envolvido no processo de aprovação da Emenda da Reeleição? A partir de análise quantitativa procedida sobre discursos que fizeram menção à Emenda da Reeleição e foram encontrados nas colunas Painel da Folha de S. Paulo e nos resumos de pronunciamentos proferidos por deputados federais e senadores nos diários oficiais da Câmara dos Deputados, do Senado Federal e do Congresso Nacional, percebeu-se que tal manifestação associativa não se deu de modo isolado.

O desafio do presente trabalho está em combinar a capacidade de análise de algo que existiu enquanto um conjunto de códigos de comunicação autonomizados (e passiveis de análise que não os reduza às determinações externas), mas que advieram em interação à pressão dos desdobramentos históricos de um período. No intuito de perceber os elementos estritamente comunicacionais, chama a atenção que a retórica em torno da aprovação da Emenda da Reeleição emite sinais que indicam a presença de um movimento autopoiético de aprovação no parlamento (LUHMANN, 2011, p. 89). Noutras palavras, identifica-se no processo de discussões e tomadas de posição dos agentes políticos envolvidos no processo de aprovação da Emenda da Reeleição a

procedimentais - típicas do moroso processo democrático de aprovação de normas por instâncias representativas do poder - antes da decretação da emenda houve uma intensa disputa política. A tramitação da matéria pelas duas casas legislativas deu-se conforme as exigências constitucionais próprias de qualquer processo legislativo de mudança constitucional: por meio de votações em dois turnos, em casa uma das Casas de Leis, e com aprovação estipulada em 3/5 (três quintos) de votos favoráveis. Foram incorporadas à Emenda promulgada pelo Congresso, em apensos totais ou parciais, questões que já haviam sido propostas em outras sete PECs: as malogradas PECs 54/1995, 58/1995, 86/1995, 113/1995, 161/1995, 172/1995 e 222/1995, todas oriundas da Câmara dos Deputados. 
presença de uma linguagem comunicativa própria, ferramenta importante para se impor politicamente sobre os opositores - algo que de maneira despersonalizada indica a ocorrência do que Luhmann classifica como sendo o encerramento operacional do sistema, com linguagem fechada em si e que permite somente o avanço de proposições que indiquem para a reprodução do próprio sistema.

Mas essa linguagem não existe em abstrato. Apesar de possuir contornos específicos (e isso poderá ser percebido na quantidade de matizes discursivas identificadas pela pesquisa empírica descrita a seguir), ela também deriva de uma série de disputas políticas existentes no contexto histórico em questão, o entorno/meio do processo político-legislativo em si. Nisso emerge a vinculação desta linguagem a um ponto de inflexão política existente nos anos 1990: a estabilização monetária brasileira advinda do Plano Real. Numa noção teórica que contempla a autonomia do processo comunicativo para aprovação da Emenda da Reeleição, os resultados indicam que houve um acoplamento estrutural entre o entorno (todo o conjunto de entendimento político-econômico e o gene institucional implantado no Estado brasileiro pelo Plano Real e seu programa de estabilização monetária) e o sistema em si (o nicho específico de onde se fez o programa de reformas que configurou a agenda de governo do primeiro mandato presidencial de FHC, incluindo a Emenda da Reeleição). De acordo com Maturana e Varela (1995, p. 112-113), um acoplamento estrutural condiz com um processo cuja interação entre dois corpos culmina em uma fixação cognitiva (de valores e códigos de linguagem) por uma unidade sistêmica, gerando um caráter estável e recorrente em suas ações de modo interdependente em relação ao que fora "acoplado". Ou seja, percebe-se pelos resultados de pesquisa dispostos a seguir que a atividade política de aprovação da emenda possuiu minúcias, mas seguiu majoritariamente um fluxo comunicacional envolvido por uma fusão de linguagens associando política e economia. Os resultados doravante dispostos apontam que Emenda da Reeleição "pegou carona" deliberadamente no Plano Real e serviu como suporte para a reprodução de seus preceitos (programa de reformas desdobrado do plano real engendrou a referida emenda, que serviu de estímulo para que o programa de reformas fosse levado a cabo com maior força). A "energia" consumida pelo sistema político adveio dessa combinação, não existindo uma determinação à priori entre elas. 
T\&P A linguagem e a agenda: uma análise de correspondência de discursos relacionados à Emenda da Reeleição (1995-1997)

O presente texto tem por objetivo central demonstrar essa associação de linguagens. Sua divisão segmenta-se em quatro partes: na primeira, revisa-se sumariamente a trajetória das disputas políticas firmadas nos anos pós-estabelecimento da Constituição Federal de 1988 (BRASIL, 1988) e de como elas assentaram-se na agenda que o primeiro governo de FHC buscou implementar; num segundo momento, faz-se breve exposição do modelo quantitativo utilizado - a identificação da associação textual dos termos-chave e a análise fatorial por correspondência; na terceira parte do presente artigo, expõe-se o conteúdo discursivo exógeno do sistema (proveniente do ambiente exterior ao sistema político, portanto, responsável por explicitar atos políticos dos envolvidos no processo de aprovação da emenda que foram monitorados pela imprensa); na quarta e última parte, analisa-se o conteúdo discursivo endógeno ao sistema (aquele proveniente imediatamente de atores políticos que trataram da Emenda da Reeleição em seus pronunciamentos).

\section{Trajetória que culminou no governo de FHC I (1995-1998) e sua agenda de reformas}

Diferentemente do que se pode imaginar, o imediato pós-promulgação de uma nova constituição não é sinônimo de interrupção de atividade política. Pelo contrário: no caso de uma constituição democrática, tende-se a acentuar naturalmente as disputas políticas, por prover liberdade e direitos que as estimulem. Essa foi a realidade brasileira pós Constituição Federal de 1988 (BRASIL, 1988). Sobretudo por conta de uma combinação peculiar ao caso brasileiro, pois a saída da ditadura levou a um choque de visões acerca da economia e da política que foram parcialmente solucionados na década de 1990.

A CF 1988 era apelidada de "constituição cidadã", e nela havia princípios aplainados como os legitimamente demandados pela sociedade. O fim da ditadura ensejava expansão de direitos sociais e a presença do Estado na defesa de minorias, da educação e da saúde pública. Clamava-se por um Estado vigoroso no atendimento à sociedade, e isso incorreria em custos materiais², em despesas para os governos. Isso foi fruto de

2 "O imaginário acerca da 'carta inflacionária' povoa a concepção relativa à nova constituição pelo menos desde o dia sete de outubro de 1988, dois dias após a sua promulgação e em pleno governo de José Sarney (1985-1990). Naquele dia a Confederação das Associações Comerciais do Brasil concluiu, em reunião, que'[...] todos os custos dos benefícios sociais aos trabalhadores previstos no texto [constitucional] serão repassados aos preços dos produtos. 'O povo é que vai pagar', disse o Presidente da Associação Comercial do Rio Grande do Sul' (EMPRESÁRIOS..., 1988). No mandato presidencial seguinte, o Presidente do Banco Central escolhido por Fernando Collor (1990-1992) disse que'a constituição é inflacionária'. Por este dizer, Ibrahim Eris aponta os alvos reformistas que deveriam ser atingidos para fins de estabilidade dos preços, referindo-se 
um processo constituinte acolhedor de amplo pluralismo decisório. Aprofundando os dados dessa disputa política, de acordo com Aragão (1996, p. 149), foram identificados, somando-se entidades públicas e privadas, cerca de 383 grupos de pressão envolvidos no processo constituinte que desaguou na CF 1988: "[...] com a aprovação de mais de 300 artigos [na constituição federal de 1988], dificilmente algum grupo deixou de ser atendido" (ARAGÃO, 1996, p. 155). Esse embate acirrou-se com o amadurecimento das condições conjunturais para a feitura de um plano de estabilização na primeira metade da década de $1990^{3}$, quando a necessidade de combate à hiperinflação passa a chocar-se mais diretamente ao desenho institucional ditado pela carta magna.

O resultado da disputa político-institucional não resolvida no processo da CF 1988 passou por uma revisão constitucional entre 1993 e 1994, em que bastaria maioria simples para aprovar medidas de modificação de seu texto, mas que foi acometida por inação decisória. Houve naquele momento uma crise parlamentar relacionada às denúncias que culminaram na Comissão Parlamentar de Inquérito (CPI) dos "anões do orçamento". O impasse nos pontos conflituosos a serem solucionados na ordem constitucional brasileira arrastou-se até o Plano Real, pois a revisão foi um momento de vitória de grupos obstrucionistas em geral (ARAGÃO, 1996, p. 158).

O ambiente político brasileiro chegou aos anos de criação e implantação do Plano Real envolvido por um processo de superação do ceticismo em relação aos caminhos a serem seguidos. A associação de custos provenientes da Constituição Brasileira à hiperinflação instigou debates políticos que clamavam por reformas constitucionais. O Plano Real incutia uma consciência de inevitabilidade de reforma da CF 1988, para que a estabilidade econômica fosse alcançada e mantida. Houve então uma gradativa escalada política do discurso de grupos sociais propensos ao alinhamento com o ideário do Plano Real. No entendimento de Aragão (1996, p. 159-160), embora o caminho para a elaboração da agenda do Plano Real não tivesse sido conduzido por meio de uma interação entre o Estado e a sociedade, em meio a métodos de participação política (por exemplo, não houve audiências públicas na elaboração das bases elementares das mudanças advindas do plano), chegava-se naqueles anos a um nível de coesão discursiva

que '[...] neste país impera este livro [...], que não permite ao governo demitir um funcionário público. Não permite que na Previdência, neste ano, o governo deixe de por uns tostões para atender alguém que também está coberto pela previdência"' (CONSTITUIÇÃO..., 1990; MIRANDA, 2015, p. 181).

3 A extensão gradativa da liquidez mundial e outros detalhes que podem ser conhecidos em Belluzzo e Almeida (2002). 
T\&P A linguagem e a agenda: uma análise de correspondência de discursos relacionados à Emenda da Reeleição (1995-1997)

entre agenda governamental e demanda da sociedade civil em que o imaginário da sociedade foi sendo, aos poucos, impregnado por princípios de reformas constitucionais ao sabor do Plano Real. Ocorreu alinhamento suficiente para uma "agenda de consenso" entre elite industrial e financeira, a grande imprensa e setores expressivos da burguesia nacional (distribuída regionalmente) que conseguiu aos poucos sedimentar-se em torno do combate à inflação. Passou-se a aceitar que essa agenda deveria ser o centro de debates para as transformações no país pelos anos seguintes.

Duas facetas podem ser consideradas numa análise sobre o pós-Plano Real: um ideológico, outro estritamente institucional, ambas com efeitos inerentemente interligados. Ideologicamente, a formação desse ambiente estatal possuía explícita propensão ao alinhamento pela via da correção fiscal para combater a hiperinflação, algo relacionado ao ideário neoliberal (ANDERSON, 1995). A difusão de ideias depreciativas em relação à capacidade produtiva e administrativa do Estado foi extensamente acatada em meados dos anos 1990. Isso ocorreu em época de casamento político entre o partido de FHC (o PSDB) e o Partido da Frente Liberal (o PFL) para as eleições de 1994. Tal aliança foi importante para que as reformas constitucionais conseguissem avançar a partir de 1995, com a maioria das propostas convergindo no sentido reforma da estrutura fiscal do Estado brasileiro. De acordo com Loureiro e Abrúcio (2002, p. 72), a estabilização monetária pós-Plano deu forças ao presidente, possibilitando "[...] uma engenharia institucional que julgava adequada para modificar o cenário macroeconômico".

Ensejou-se assim uma série de propostas de reformas, e elas concentravam-se no capítulo da ordem econômica da CF 1988. Seus conteúdos estavam ligados ao ideário de reforma do Estado no sentido de minimização de suas funções produtivas, aquilo que fora dito como a "superação da Era Vargas" presente na agenda de reformas do primeiro mandato de FHC (COSTA, 2002). Já as propostas de reformas administrativa, tributária e da previdência não tiveram uma condução linear, pacificamente aderidas por parte da maioria do parlamento. Para além do ideário liberal de contenção fiscal, todas elas sofreram ou acentuada alteração nas propostas originais - as reformas da previdência e administrativa -, ou tiveram impedimentos viscerais e tiveram somente um mini-pacote aprovado no segundo mandato de FHC - caso da reforma tributária (MELO, 2002). Certamente, o fato de as mudanças estarem situadas na ordem econômica produziam algumas dificuldades. Além disso, no entendimento de Couto e Abrúcio 
(1999, p. 20-21), trata-se de algo normal a presença de dificuldades de aprovação dessas matérias, pois a arena decisória no legislativo demandava 3/5 de votos para as mudanças constitucionais, e isso acarretava na necessidade de uma coalizão deveras custosa para o governo.

Apesar das dificuldades relatadas, houve significativa imposição de agenda por parte do poder executivo. A análise de Couto e Arantes (2002) expressa o resultado da força legislatória do governo, estendendo-a até o final do segundo mandato de FHC:

As 34 emendas constitucionais aprovadas durante os oito anos do governo de Fernando Henrique Cardoso são um indicador inconteste do fato de que durante este período o país viveu uma autêntica agenda constituinte, afinal de contas aprovaram-se na média 4,25 emendas por ano. Considerando-se que entre 1988 e 1994 apenas outras quatro haviam sido aprovadas (excetuadas as seis Emendas de Revisão de 1994), o número impressiona. (COUTO; ARANTES, 2002, p. 93).

O sistema esteve subjugado a um complexo de transformações mais amplas e duradouras, à mudança do Estado, definindo a preponderância de grupos sociais específicos sobre a influência nos rumos do país - tal como apresentado no jogo de lobbies presentes no Congresso revisor constituinte. Numa tentativa de síntese entre o ideológico e o institucional, afirma lanoni (2009) que o Plano Real operou uma grande virada pois foi responsável pela afirmação de uma nova ordem político-institucional que determinou uma refundação da distribuição de poder político na sociedade brasileira 4 .

O Plano Real foi uma grande oportunidade conjuntural que colocou a política brasileira a reboque de sua finalidade, reposicionando-a estruturalmente e criando raízes para o futuro das instituições brasileiras - e estas foram o espaço de desenvolvimento autopoiético que se verá na descrição do trabalho empírico a seguir. De acordo com Ianoni (2009, p. 173), a doutrina econômica do real é o eixo fundador de um novo Estado:

4 Na concepção de Poulantzas (1980), a principal referência de lanoni (2009), um novo Estado pode advir por meio de uma nova correlação de forças políticas congregadas por classes sociais em disputa em que, como consequência, um grupo social passou a deter o poder institucional, preenchendo hegemonicamente as decisões políticas. Ainda que legítima a consideração do sistema político como categoria analítica, ela só pode ser vista em um plano inferior ao Estado e para análises específicas, como o entendimento de distribuição ativa de "papéis e funções" no exercício de poder de representantes e burocratas (EASTON, 1970). Num passo adiante, o presente artigo ainda lança mão de conceitos de outros autores da teoria dos sistemas (LUHMANN, 2011; MATURANA; VARELA, 1995), tendo em vista a necessidade de percepção de elementos expressamente autonomizados nos códigos de linguagem políticos empiricamente analisados. Ainda assim, mesmo analisando o sistema político primordialmente não se pode perder de vista a correlação de forças político-sociais que o dirige, pressiona e forma o meio/entorno do sistema. 
[...] o Plano Real viabilizou a repactuação sociopolítica, inclusive o seu acabamento na esfera político-institucional pela aliança de centro-direita. [...] foi um programa gerador de força centrípeta que reconstruiu o consenso do qual emergiu o Estado pós-nacional-desenvolvimentista. O Plano Real expressou e conduziu ao poder uma vontade "coletiva" liberal, núcleo ideológico que capturou o interesse público anti-inflacionário.

Ou seja, por fim, um plano de exacerbada delimitação técnica como o do Real fora capturado ideológica e socialmente. Referindo-se às forças políticas, o referido autor explica que a chegada do plano veio à tona em conformidade com um momento histórico cuja característica era possuir um "exército liberal até então sem general", uma composição de empresários e rentistas interessados nos impactos financeiros do Plano que se efetuara (IANONI, 2009, p. 178).

Complementando tal descrição do entorno político-econômico daquele momento, percebeu-se a existência de uma argamassa comunicativa entre a emergência desse novo Estado e o funcionamento dos sistemas econômico e político a ele condizentes, algo que salta aos olhos no processo político-legislativo de aprovação da Emenda da Reeleição. Isso é percebido no amálgama discursivo expresso nesse processo.

\section{Metodologia de análise dos padrões discursivos relacionados à Emenda da Reeleição}

A presente análise preocupa-se em desvelar o que se disse sobre os políticos engajados no processo legislativo da Emenda da Reeleição, isto tido por discursos exógenos, e sobre o que eles disseram em relação a esse evento, estes os discursos endógenos ao processo político-legislativo. Sendo assim, o horizonte de alcance das descobertas de existência de um padrão discursivo em torno da Emenda da Reeleição torna-se inicialmente algo impossível de ser abrangido. Faz-se assim a necessidade de circunscrição a algumas publicações da imprensa, algo exigido para tornar viável a execução da pesquisa. Desse modo, foi elaborado um recorte procedimental sobre as fontes pesquisadas, selecionando publicações que correspondessem aos dois objetivos de pesquisa supradispostos.

A seleção do material e o modo de proceder a análise diz respeito à busca por equilibrar capacidade analítica e exequibilidade do trabalho de pesquisa. Desse modo, selecionou-se 
os textos das colunas Painel da Folha de S.Paulo e os resumos de pronunciamentos parlamentares presentes no Diário da Câmara dos Deputados, do Diário do Senado Federal e do Diário do Congresso Nacional ${ }^{5}$. Todos os textos selecionados possuem menção direta ao instituto da reeleição presentes ao de seu processo legislativo, ou seja, textos relacionados ao assunto e publicados entre janeiro de 1995 e setembro de 1997. A amostra culminada do material foi de 467 colunas Painel e 1.723 resumos de pronunciamentos.

A inserção desse material em um software de análise estatística possibilitou a utilização de metodologia quantitativa na análise. A contribuição disso se deu por meio da precisão estatística do programa Iramuteq (CAMARGO; JUSTO, 2013; SALONE, 2013), responsável por prover os resultados da análise léxico-estatística dos textos. Ele serviu para mensurar a manifestação de palavras (formas léxicas) nas colunas e nos pronunciamentos, identificando como elas associavam-se umas às outras para formar segmentos textuais portadores de sentido uno e coeso. A partir dessa associação, foi possível a descoberta de proximidade entre os termos que se uniam para compor uma explicação e produzir o significado de uma ideia no texto:

[...] [o segmento de texto] é entendido como uma espécie de representação elementar, um sentido ou um enunciado mínimo em um discurso. Tal enunciado é postulado como uma idéia de um indivíduo psíquico, sendo que essa idéia se refere a um objeto, mas também, ao mesmo tempo, ao próprio sujeito. É essa dupla referência que permite a formação da representação de um objeto. Por extensão, a regularidade de representações entre indivíduos pode promover a existência de um determinado contexto típico de um grupo, uma representação coletiva, um "mundo" [de conceitos e valores]. (NASCIMENTO; MENANDRO, 2006).

Entre todos os recursos presentes no Iramuteq, utilizou-se o seguinte caminho para se chegar aos resultados que serão apresentados e discutidos doravante. Os segmentos de textos utilizados para interpretação advieram do processo de cálculo do software iniciado com a distribuição de frequência das formas (as palavras) mais comuns. Há ainda uma depuração das formas ativas (palavras selecionadas pelo pesquisador, no presente

5 Essa seleção foi feita por ter em vista a relevância das publicações em seus acompanhamentos dos eventos políticos ligados ao processo legislativo da Emenda da Reeleição: a coluna jornalística em questão é uma destacada publicação voltada para noticiar minuciosamente os bastidores da política nacional, presente no jornal de maior circulação do país; os três diários oficiais citados possuem exatamente os discursos dos parlamentares nas sessões plenárias do legislativo federal, ou seja, quando o assunto foi abordado por algum deles com certeza esteve publicado nesses locais. 
T\&P A linguagem e a agenda: uma análise de correspondência de discursos relacionados à Emenda da Reeleição (1995-1997)

caso considerou-se os substantivos, os adjetivos e os verbos presentes nos textos), separadas das menos relevantes. Inicialmente, o programa indica quais delas estiveram presentes no texto matricial ${ }^{6}$ submetido e quais as suas quantidades de ocorrência (SALONE, 2013, p. 3-4). Pelo fato das palavras de um texto corresponderem a dados categorizados, o modo com que é aferida a distância entre os termos dá-se por meio do teste estatístico de $x^{2}$ (qui-quadrado) (BARBETTA, 2011, p. 228). Após a contagem das formas, o programa efetua esse teste para indicar o nível de significância entre elas e apontar a associação direta entre os termos. Colocadas em relação, as formas que possuírem resultado de qui-quadrado que demonstrem significância serão consideradas mais próximas, sendo assim mais forte e diretamente associadas e formando segmentos textuais coesos ${ }^{7}$. No computo efetuado pelo Iramuteq, de acordo com o valor revelado em $x^{2}$ que demonstre significância, maior a tendência de que haja mínima diferença entre as frequências observadas e as frequências esperadas da manifestação da forma léxica numa classe.

Após a aplicação do teste e a identificação das associações entre as formas e os segmentos de textos advindos delas, elabora-se por intermédio do programa uma distribuição de frequência das associações. São identificados os segmentos de texto que possuem maior associação direta, distinguidos dos que possuem menos associação direta por meio de uma distribuição de frequência intitulada classificação hierárquica descendente (CHD). Ela cria um dendrograma (um filograma, diagrama em forma de árvore) que classifica quais as formas e seus respectivos segmentos textuais que se assemelham, quais as suas frequências percentuais no texto e como elas convergem em associação ou se tornam independentes das demais (SALONE, 2013, p. 4). Isso possibilita a elaboração de clusters (classes textuais) compostos por formas e segmentos textuais com forte associação e seus respectivos contrafactuais. Há portanto uma definição individual de classes textuais, espécies de blocos de segmentos de texto que são

6 O texto matricial passou por um rigoroso tratamento antes de ser submetido ao programa. Para o devido reconhecimento da matriz, houve a necessidade de adequar todas as palavras compostas (inserindo o caractér _ entre elas) e de buscar uma padronização comum no texto (por exemplo, havia grande quantidade de termos distintos, porem com os mesmos significados, como Fernando_Henrique_Cardoso e FHC. Eles tiveram de ser padronizados, no intuito de dar precisão à quantificação de suas manifestações textuais).

7 O programa possui um dicionário capaz de identificar o tipo da forma (substantivo, adjetivo, pronome, verbo, advérbio, artigo, dentre outros) e a pontuação do texto. Ou seja, não são somente contadas as palavras, mas também associadas perante os seus excertos, sem mutilar a coesão de frases e orações. O presente trabalho considera somente os resultados expressos pelo software que tiveram a distribuição do $x^{2}$ processados por um Grau de Liberdade $g l=1$ e os resultados considerados tiveram um nível de significância $p<0,001$ (altamente significante) nas associações. 
portadores de significados comuns, mas distintos quando postos em comparação entre elas (variáveis independentes) ${ }^{8}$.

Por fim, chega-se à etapa estatística de análise de correspondência. Todo o complexo de classes textuais produzidas e expostas pela CHD é inserido num modelo chamado análise fatorial por correspondência (AFC). Além da descrição das classes textuais individuais, que podem ser definidas como variáveis explícitas e em associação direta em um texto, existe a possibilidade de se descobrir também a existência de variáveis latentes e associadas indiretamente (FIELD, 2009, p. 553; FIGUEIREDO FILHO; SILVA JÚNIOR, 2010, p. 162). Para tanto, efetua-se uma análise fatorial, que tem por finalidade descobrir medidas subjacentes às variáveis explícitas (os "fatores comuns" entre elas), agregando as principais formas constituidoras de todas as classes textuais. A exposição gráfica da análise fatorial dá-se por meio da inserção de uma ampla gama de formas léxicas de distintas classes entrecruzando-se em um mesmo plano. No caso do presente estudo, possibilita-se uma comparação sincrônica que revele a existência dos dois fatores mais relevantes para analisar correlações entre comportamentos e ideias relativos ao processo legislativo narrado no capítulo anterior - será útil para testar o que está explicito para descobrir o que é implícito no conjunto de relações travadas para aprovar a Emenda da Reeleição.

\section{A associação discursiva exógena aos agentes políticos}

O conjunto textual voltado para a análise do que se disse sobre os políticos engajados no processo legislativo da Emenda da Reeleição foi caracterizado por 182.814 ocorrências totais de palavras, em 15.162 formas léxicas distintas. As principais palavras para a atribuição

8 Para fins analíticos, destaca-se que a formação de classes contrafactuais indica a estrita necessidade de que se compare e discorra a respeito dos resultados com significância $p<0,0001$, pois resultados "neutros" ou com tendência inversa de associação estarão situados nos contrafactuais (que condizem ao inverso de tendência de associação entre formas e segmentos textuais no interior da classe).

9 No caso do resultado produzido pelo Iramuteq para esta tese, foram visíveis em um mesmo plano as classes, as formas reduzidas e os eixos fatoriais. Para o lançamento disso num mesmo plano, o tratamento dos dados foi feito por meio de uma disposição dos fatores através de um cálculo de medida correlação entre as variáveis (apresentadas no Iramuteq como Classes) chamada de rotação oblíqua. Isso proporciona ao modelo um resultado de covariância comum capaz de indicar como se correlacionam as classes de um conjunto textual (que indica comportamento ou ideias políticas) em um número reduzido de fatores (para o presente trabalho, dois foram os definidos para cada AFC). Apesar da alta complexidade envolvida na decomposição de tantos elementos em um mesmo modelo analítico, é simples a lógica da AFC aqui utilizada: quanto mais próximo um elemento estiver do outro no plano gráfico, mais ele possui "falas" em comum; do contrário, quanto mais distante no plano fatorial estiverem dois elementos, deve-se efetuar interpretação para entender como se forma entre eles uma correlação de oposição (NASCIMENTO; MENANDRO, 2006, p. 78; FIGUEIREDO FILHO; SILVA JÚNIOR, 2010, p. 169). 
de significado nos textos, correspondentes às formas ativas, foram encontradas em um total de 7.582. As quinze mais frequentes delas foram os substantivos FHC (1.462 vezes), reeleição (934), PMDB (825), governo (805), SP (relativo à cidade de São Paulo, 721), câmara (709), PFL (691), partido (552), PSDB (528), planalto (506), PT (489) e Maluf (454), e os verbos dizer (991), querer (523) e dever (422).

No âmbito agregado puro, percebe-se a centralidade da manifestação de formas como FHC, reeleição e governo (as três naturalmente condizentes com o foco inicial da busca, com o proxy da busca). Porém, vale a pena observar quais são as que orbitam entre elas e apresentam-se também entre as mais frequentes. Desse modo, percebe-se que as formas PMDB, Câmara, PFL, PT e Maluf (o nome de um ator político individual) possuem majoritariamente relevância nos textos, prenunciando que foram ampla e reiteradamente anunciadas ao longo do conjunto de colunas Painel de janeiro de 1995 a setembro de 1997. Isso significa que a busca por informações de bastidores a essas referências foi crucial ao longo do processo legislativo, sendo os atores complementares da operação de aprovação da Emenda da Reeleição de FHC.

Além do quantitativo agregado de formas, o processo de interpretação delas precisa avançar pela associação em pleno texto. Nesse sentido, o teste de associação estatística percebeu a presença de 4.988 formas especificamente associadas a 5.066 segmentos de textos. Eles foram agrupados em seis classes distintas (ver Tabela 1), distribuídos pelo seguinte percentual e nível de associação (ver Gráfico 1).

Apreende-se nos resultados que a primeira classe foi composta por 10,5\% dos textos relacionados ao movimento político de aprovação da reeleição - num total de 525 formas. Chama a atenção que essa classe abordou aquilo que pode ser percebido como o momento de menor tensão no processo legislativo da PEC 01/1995: seus textos abordam procedimentalidades relacionadas ao momento de tramitação da PEC na Comissão Especial da Câmara dos Deputados. Tanto que se sobressai nessa classe a associação forte com as formas Comissão Especial $\left(x^{2}=168\right)$, relator $\left(x^{2}=120\right)$ e Franco (sobrenome do relator da proposta, Vic Pires Franco) $\left(x^{2}=102\right)$. Destaca-se nessa classe a ausência de menções a nomes de políticos ou de partidos da oposição, e as suas publicações mais significativas estiveram situadas nos meses de março de 1996 (momento em que o processo legislativo da emenda passava por um hiato decisório) e janeiro de 1997 (quando a Comissão Especial facilmente aprovou o relatório de Franco). 


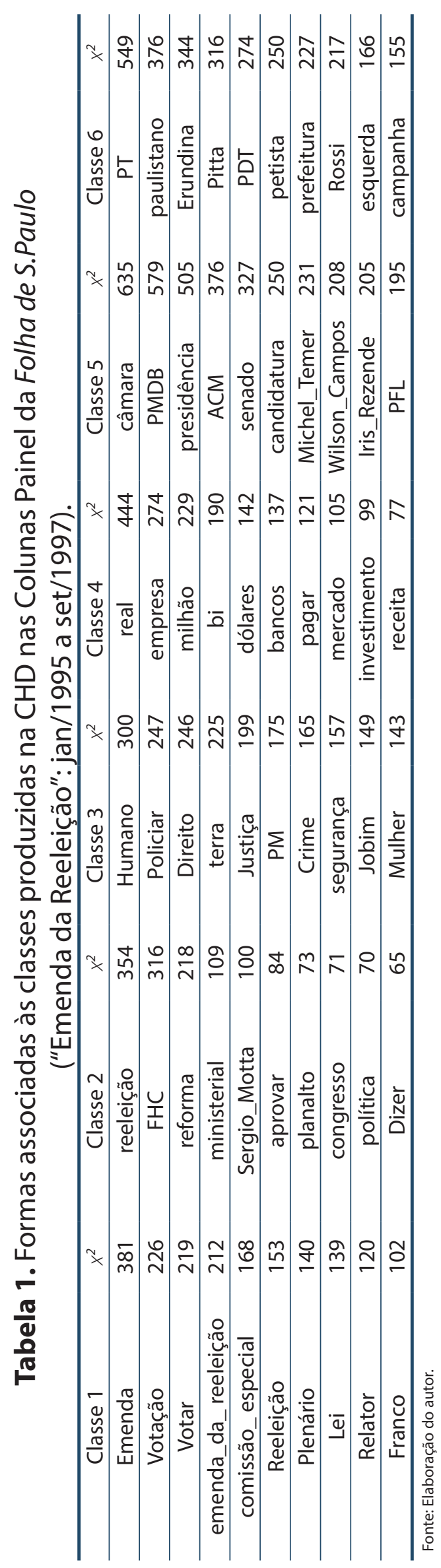




\section{Gráfico 1. Dendrograma de CHD dos Segmentos Textuais nas Colunas Painel da Folha de S.Paulo ("Emenda da Reeleição": jan/1995 a set/1997).}

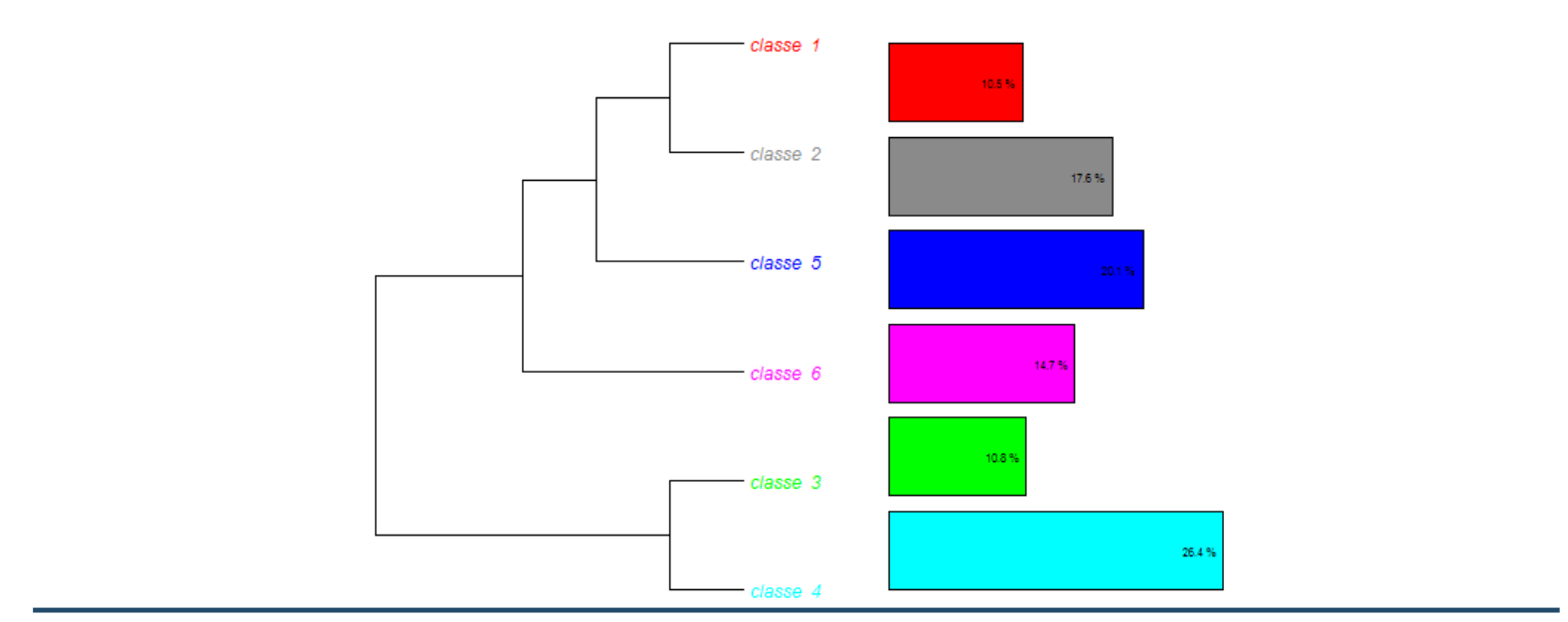

Fonte: Colunas... (1997).

As expressões verbais relativas a votar $\left(x^{2}=219\right)$ e o substantivo votação $\left(x^{2}=226\right)$ indicam como o interesse das informações de bastidores era em indicar como havia praticidade no trabalho da comissão. Interessava-se por agilizar o voto em prol da emenda.

A segunda classe possui um percentual maior de incidência sobre o conjunto das colunas Painel, apresentando-se em 17,5\% do texto, ou 877 formas léxicas ativas entre o total que dá significado às colunas. Essa classe possui segmentos textuais característicos de meses de hiato processual da emenda, situando-se principalmente em abril, agosto, setembro e outubro, bem como adentrando também os momentos de retomada do processo, em novembro e dezembro de 1996. Conforme o dendrograma, seu conteúdo possui relativa associação com a Classe 1. Todavia, é marcante como ele expressa situações de conflito atinentes às relações políticas do momento, diferenciando-se da anterior. Além das dez formas mais associadas e dispostas na Tabela 1, há também uma série de menções que associam os segmentos textuais a Maluf $\left(x^{2}=43\right)$, ao PPB $\left(x^{2}=50\right)$, à proposta de plebiscito $\left(x^{2}=65\right)$ e a Itamar Franco $\left(x^{2}=49\right)$. Em geral, são evidenciados os movimentos políticos do governo para tentar conter conflitos com esses agentes oposicionistas. Dois termos vizinhos no ranking de associação (reforma, $x^{2}=218$, e ministerial, $\left.x^{2}=109\right)$ podem ser identificados como termos do interesse do governo para desarmar a oposição e conquistar governabilidade. Os nomes de governo significativamente associados, como o do Presidente FHC $\left(x^{2}=316\right)$, do substantivo planalto $\left(x^{2}=73\right)$ e dos 
recorrentes articuladores políticos Sérgio Motta $\left(x^{2}=100\right)$ e de Luiz Carlos Santos $\left(x^{2}=27\right)$ dão mostras do interesse do governo no assunto.

A terceira classe de expressões corresponde a um bloco de eventos e discursos políticos responsáveis por 10,8\% da totalidade dos textos compilados, sendo o segundo menor percentual de todo o conjunto textual da coluna Painel (corresponde a 539 formas).Todavia, trata-se de menções políticas ligadas a eventos mais originais em relação aos demais, em virtude de serem ideologicamente orientados e distantes do processo legislativo da Emenda da Reeleição per se. Eles correspondem a uma série de enunciados de ações políticas ligadas a questões relacionadas aos direitos humanos (humano, $x^{2}=300$ ), ao MST, à luta pela terra e a problemas relacionados à segurança pública e à criminalidade brasileira (terra, $x^{2}=225$, justiça, $x^{2}=199$, crime, $x^{2}=165$ e segurança, $x^{2}=157$ ). O momento de maior significância no valor de $x^{2}$, entre todos os que possuíram segmentos textuais caracterizados pela Classe 3, foi o mês de abril de 1997. Não à toa: havia intensa preocupação do Governo de FHC naquele mês em dar respostas a mobilizações de movimentos sociais, em meio à marcha do MST que ocupou Brasília (um ano após o massacre de Eldorado dos (arajás).

Ao referir-se à Classe 4, chega-se ao conjunto de segmentos textuais proporcionalmente mais importante de toda a amostra pesquisada, com frequência de 1.315 formas ativas. Tal como a sua antípoda associativa, a Classe 3, há nela um forte teor ideológico em seus 26,4\% de ocupação das colunas Painel. O resultado qui-quadrático mais destacado dela está na forma que dá nome à moeda brasileira: o real $\left(x^{2}=444\right)$. Outras que surgem são empresa $\left(x^{2}=274\right)$, milhão $\left(x^{2}=229\right)$, bi (relativa à forma bilhões) $\left(x^{2}=190\right)$, dólares $\left(x^{2}=142\right)$, bancos $\left(x^{2}=137\right)$, mi (relativa à forma milhões) $\left(x^{2}=113\right)$, mercado $\left(x^{2}=105\right)$, investimento $\left(x^{2}=99\right)$, receita $\left(x^{2}=77\right)$, orçamento $\left(x^{2}=75\right)$, dinheiro $\left(x^{2}=71\right), B C$ (relativa ao Banco Central, $\left.x^{2}=69\right)$, entre tantas outras formas léxicas em notas jornalísticas que procuravam expressar o cotidiano dos negócios políticos do Governo de FHC. Há destaque para a manifestação de segmentos textuais contidos por essas formas em maio de 1995, fevereiro de 1996 e março de 1997, mas em geral elas permeiam praticamente todo o período da amostra pesquisada.

Esse é o núcleo duro da retórica da estabilidade (MIRANDA, 2015). Tais expressões disseram respeito a relações políticas ocorridas em 1995, 1996 e 1997. Elas giraram em torno da reforma da ordem econômica da Constituição, dos programas de recuperação 
T\&P A linguagem e a agenda: uma análise de correspondência de discursos relacionados à Emenda da Reeleição (1995-1997)

dos bancos (PROER), dos planos de privatizações das empresas estatais, às discussões para aprovação do Fundo de Estabilização Fiscal (FEF) e demais propostas de reformas constitucionais (como a administrativa e a da previdência), ou estão presentes na discussão o déficit fiscal produzido pelos valores de repasses feitos a bancadas e a deputados individuais através de emendas ao orçamento da União, ou nas apurações da CPI dos precatórios. Enfim, é tamanha a capilaridade desses segmentos textuais dentre as notícias de bastidores do governo que ela permeia a todos os momentos pesquisados. Pode-se dizer que praticamente todas as vezes em que havia um texto na coluna Painel da Folha de S.Paulo mencionando a Emenda da Reeleição havia também algum segmento do texto que tratava de algum negócio feito com recursos públicos. Não é de se estranhar tal fato, por condizer com a agenda política do Governo de FHC.

Retomando descrição e análise dos blocos quantitativos de informações de bastidores da política, pode-se dizer que a Classe 5 corresponde ao segundo maior conjunto de formas léxicas, abrangendo 20,1\% das colunas Painel, equivalente a 1001 formas. Majoritariamente, estão perfilados nessa composição dois assuntos: os conflitos internos do PMDB ( $\left.x^{2}=580\right)$ em janeiro de 1997 e as articulações para as eleições para presidência da Câmara $\left(x^{2}=635\right)$ e do Senado $\left(x^{2}=327\right)$ ocorridas entre dezembro de 1996 e fevereiro de 1997. A abordagem desses temas pelos segmentos textuais dessa classe possui como aspecto principal a articulação política entre o Governo de FHC e os seus aliados no Congresso. Assuntos como a disputa da eleição para a chefia legislativa, da presidência do Senado, os conflitos por espaço que acirraram as disputas entre PFL e PMDB na coalizão de governo na Câmara, a situação do PPB face ao governo, a convenção nacional do PMDB em meados de janeiro de 1997 e a eleição de Michel Temer são os elementos significantes nessa classe.

Por fim, a última classe com um padrão textual específico tem identidade relativa à movimentação política produzida pelas eleições municipais de 1996. A Classe 6 correspondeu a 14,7\% (731 formas), ocorreu sobretudo nos meses de setembro e outubro daquele ano e possuindo larga presença de atores políticos individuais, que buscavam influenciar o voto em diversas eleições municipais. A forma léxica com maior nível de associação nela foi PT ( $\left.x^{2}=549\right)$, algo que significa a existência de importância política do partido naquele processo eleitoral, mas também denota a ausência de relevância do partido em articulações políticas remetidas às outras cinco classes discursivas. Algumas formas 
relevantes nela foram Erundina $\left(x^{2}=344\right)$, Lula $\left(x^{2}=95\right)$, Dirceu $\left(x^{2}=75\right)$, Mercadante $\left(x^{2}=62\right)$ e Genoíno $\left(x^{2}=60\right)$, confirmando a importância do PT naquele pleito, bem como Serra $\left(x^{2}=142\right)$, Pitta $\left(x^{2}=316\right)$, Malufismo $\left(x^{2}=91\right)$ e Rossi $\left(x^{2}=217\right)$, todos termos relativos às eleições paulistanas.

Após a descrição das classes, uma análise fatorial baseada em um modelo de rotação oblíqua (direct oblimin) foi utilizada (FIELD, 2009, p. 568). O interesse da inserção desse modelo analítico diz respeito à necessidade de perceber o modo como se correlacionaram as formas apresentadas no texto e as classes às quais elas pertencem. Isso possibilitou a descoberta de fatores subjacentes, que proporcionaram ligação e organização de segmentos de texto e comportamentos políticos relacionados à Emenda da Reeleição que foram relatados pela coluna Painel. Utilizou-se a medida de adequação geral de Kaiser-Meyer-Olkin, KMO (PALANT, 2007 apud FIGUEIREDO FILHO; SILVA JÚNIOR, 2010) com o valor aferido em 0,692.

O primeiro passo foi estabelecer os resultados dos autovalores dos fatores ${ }^{10}$, pois ele possui a função de identificar os níveis de correlação entre as classes textuais. Os dois valores mais altos dentre os cinco identificados corresponderam aos fatores agregadores mais importantes da amostra (ver Gráfico 2). O Fator 1 concentrou 33,14\% das relações no conjunto do texto, o Fator 2 alcançou 20,88\% delas, com a possibilidade de uma análise fatorial com 54,02\% de porcentagem acumulada de relações entre as variáveis/classes textuais.

O processamento da análise levou em conta o nível de significância do $x^{2}$ das formas ativas de cada classe, para que a análise tratasse objetivamente de expressões fortemente associadas a cada classe, e que a análise nos fatores pudesse ficar límpida para fins de identificação disso (caso fossem lançadas as quase cinco mil formas, a análise ficaria confusa). Desse modo, foi processada amostra estratificada proporcional com 814 formas (100\% das significantes), 112 na Classe 1 (13,7\%), 79 na Classe 2 (9,7\%), 177 na Classe 3 (21,7\%), 227 na Classe 4 (27,8\%), 101 na Classe 5(12,4\%) e 118 na Classe 6 (14,5\%).

Basicamente, a distribuição correlacional do grande volume de dados utilizados indica que o Fator 1 diz respeito à incidência do processo legislativo da Emenda da Reeleição. Quanto maior a carga de uma forma ou classe nesse fator, mais ao centro do referido

10 Os autovalores encontrados foram: de 0,263 considerando de um lado as Classes 3 e 4 e de outro as Classes 1, 2, 5 e 6; de 0,165 quando considera-se as relações com a Classe 6 de um lado e as Classes 1, 2 e 5 de outro. 


\section{Gráfico 2. AFC (correlação entre formas e Classes). Colunas Painel da Folha de S.Paulo ("Emenda da Reeleição": jan/1995 a set/1997).}

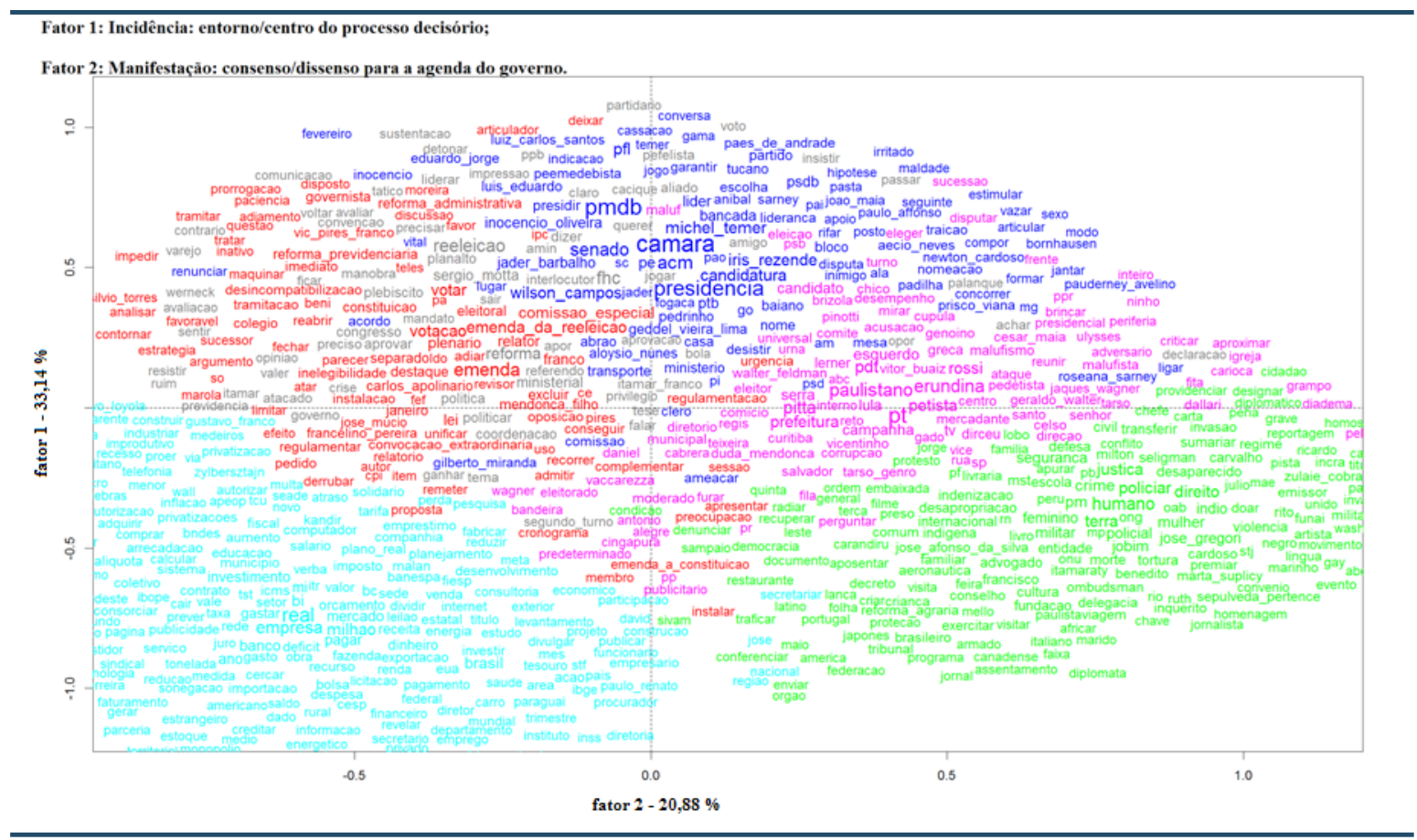

Fonte: Colunas... (1997).

processo decisório elas estarão, como é o caso das classes 2 e 5 e de algumas formas, como o nome de Luiz Carlos Santos, do PFL e de Paes de Andrade (criador de grande confusão no mês de janeiro de 1997) e adjetivos como partidário ou articulador. Em contrapartida, quanto mais negativa for a carga nesse fator, mais relacionadas com o entorno do estrito processo decisório serão as classes e formas, e isso se dá com as classes 3 e 4 e os seus grandes volumes de formas com valor associativo significante

Por outro lado, os domínios de influência do Governo de FHC estão manifestos no Fator 2. Portador de conteúdo mais aproximado da agenda política do governo, a principal característica dos elementos que possuem cargas fatoriais altas nele diz respeito a controvérsias e a dissensos evitados por FHC para proceder suas ações. A agenda política do Governo de FHC foi basicamente a agenda de reformas constitucionais baseadas na remodelagem fiscal do Estado impingida pelo Plano Real (COUTO; ABRÚCIO, 1999) e movida por tentativas de alteração que visavam alterações constitucionais que envolviam a reestruturação do Estado por meio de tentativas de reforma tributária, previdenciária e administrativa (MELO, 2002). A literatura pós-plano de estabilização indica também a presença de uma pauta proveniente da formação de uma nova correlação de forças 
políticas desde a sociedade (ou seja, a formação de um novo Estado demandou isso) (IANONI, 2009).

As classes 3 e 6 estão quase integralmente concentradas nos níveis mais altos do fator 2 , com nomes relacionados sobretudo a temas como direitos humanos e ao antagonismo eleitoral a FHC reveladas nas eleições de 1996. Cita-se os parlamentares e candidatos de oposição (como Marta Suplicy e Luiza Erundina), bem como o nome do secretário nacional dos direitos humanos à época (José Gregori). Esse "campo da controvérsia" da alta carga do fator em questão possui também a manifestação da Classe 5. Ainda que mais leve que as outras duas, ela exprime nas figuras de Pauderney Avelino (PFL-AM, acusado de intermediar a compra de votos para a Emenda da Reeleição) e Roseana Sarney (PFL-MA, filha de José Sarney e em incerta posição de "apoio" à Emenda da Reeleição) a presença de formas léxicas que indicam as dificuldades para o governo conseguir maioria na aprovação da emenda, principalmente, no âmbito das negociações para as eleições das presidências da Câmara e do Senado (algumas das formas com maior nível de significância nessa classe). Os níveis negativos de carga fatorial indicam as variáveis consensuais em relação ao domínio de influência para o governo: menções feitas às privatizações, a reformas econômicas e a negociações políticas da comissão especial que analisou a emenda (a forma verbal contornar e o substantivo paciência possuem essa característica) indicam o sentido e a atividade política em prol da agenda do governo.

Reflexos de tensões ideológicas e procedimentais são perceptíveis nas correlações entre formas e classes por meio dos dois fatores preponderantes. Há uma clivagem ideológica entre as classes 3 e 4, cuja correlação é perceptivelmente negativa, sobretudo pela primeira delas. Dividindo o segundo fator ao meio, percebe-se o lado esquerdo como uma zona de influência preponderante do governo: assentado sobre a base das mudanças econômicas advindas do Real, desdobram-se acima delas as atividades políticas que estreitam relações com parceiros preferenciais (o PFL), e até com figuras como Esperidião Amin (PPB-SC) e com o PMDB sendo puxado para esse campo, com o peso da influência do governo sobre o Senado e sobre peemedebistas da cepa de Michel Temer. Esses elementos da Classe 5 foram fundamentais para aspirar a política para um centro, reduzir a polarização e produzir governo. Já do lado direito do Gráfico 2, tem-se um campo de influência que não é passível de controle do governo (nas origens ou nos efeitos dos atos), com a incipiente gestão sobre a anomia ocorrida pré-votação das 
T\&P A linguagem e a agenda: uma análise de correspondência de discursos relacionados à Emenda da Reeleição (1995-1997)

presidências legislativas (ainda que efetiva, pois deu certo ao final) e principalmente com os conflitos advindos da Classe 3. Especificamente a respeito dela, manifesta-se um nível de dispersão acentuado em relação ao resto do sistema de relações políticas aqui captado, o que tem a ver com algumas de suas características anti-institucionais, como as mobilizações do MST, e a impermeabilidade da agenda de FHC sob a égide do Plano Real.

Pode-se afirmar qual foi o arranjo combinatório das correlações que sustentaram o processo decisório no governo FHC. A Classe 4 apresentou-se de modo consistente para figurar como base da agenda do governo. A Classe 5 "centrou" e deu governabilidade por meio de menção à grande negociação política daquele momento - as presidências legislativas. Sobre a influência da Classe 3, ela foi altamente dispersa e não incidiu sobre o centro decisório. E, por fim, deve-se destacar a importância da discreta Classe 2. A ausência de qualquer força de correlação de sua parte indica a presença de alguns elementos importantes para se atentar. Ela possuiu uma dispersão que não comprometeu a sua incidência sobre o Fator 1, tendo como destaque as formas reforma ministerial, Sérgio Motta e uma série de formas verbais, típicas de pequenas negociações políticas. Isso indica como ela combinou-se às condições presentes nas demais classes para que se garantisse o sucesso do governo na aprovação da emenda.

\section{A associação discursiva endógena aos agentes políticos}

A partir desse momento, o foco de análise do presente trabalho desloca-se para o que disseram os agentes políticos congressuais que mencionaram a Emenda da Reeleição em suas falar na Câmara, no Senado e nas sessões do Congresso Nacional (a junção extraordinária das duas casas). Far-se-á o mesmo percurso analítico anterior, mas especificamente voltado para os discursos endógenos ao processo legislativo da Emenda da Reeleição, por meio de dados recolhidos de resumos de pronunciamentos entre janeiro de 1995 e setembro de 1997.

A análise estatística dos diários das casas legislativas levou em conta um N total de 1.723 resumos de pronunciamentos. Eles foram produzidos por 358 parlamentares (60,4\% dos 594 congressistas federais brasileiros), com representantes das 27 unidades da federação, eleitos em 1994 por 14 partidos distintos (82,3\% dos 17 partidos que alçaram 
representantes no parlamento naquela oportunidade). Desse total, desagregam-se os dados em 303 deputados (84,6\% dos que mencionaram a Emenda da Reeleição em seus discursos, 59\% dos 513 deputados da Câmara) e 55 senadores (respectivamente 15,4\% do total dos parlamentares, 68\% dos 81 senadores).

O processamento dos resumos de pronunciamentos no /ramuteq computou amostra com 78.568 ocorrências de formas léxicas, distribuídas em 2.697 segmentos de texto e 4.399 formas ativas. Destas, as quinze portadoras de maior frequência no conjunto do corpus textual submetido ao Iramuteq foram os substantivos reeleição (707 vezes), artigo (446), executivo (399), proposta (383), casa (355), cargo (317), mandato (304), votação (281), aprovação (279), detentor (271), constituição (269) e FHC (248), os adjetivos federal (352) e nacional (339) e o verbo publicar (296).

No âmbito agregado puro, a importância de todos esses termos é um tanto quanto óbvia. Eles condizem ou com a técnica legislativa (artigo e proposta, por exemplo), ou com a matéria que fora objeto de pesquisa na base de dados dos diários (a reeleição). Portanto, a quantidade agregada de ocorrências pouco contribui para identificar as peculiaridades dos pronunciamentos atrelados à Emenda da Reeleição.

A desagregação e sistematização delas deu-se por meio de cinco classes (ver Gráfico 3 e Tabela 2) identificadas pela Classificação Hierárquica Descendente (CHD) do corpus textual.

A Classe 1 ocupa o percentual de 23,1\% do total de análise, figurando como a de maior frequência junto da Classe 5 (que tem 23,2\%, praticamente um empate de resultado). Ela tem por principal característica a presença de segmentos textuais fortemente identificados com a agenda de reformas do Governo de FHC. Sobressaem-se nela as associações a temas econômicos, como a privatização da Vale (a empresa de mineração Companhia Vale do Rio Doce, $x^{2}=62$ ), e a menção direta à reeleição do presidente da república $\left(x^{2}=64\right)$. Não figurando entre os dez mais importantes, mas também presentes e detentoras alto nível de significância associativa a essa classe estão formas como política econômica $\left(x^{2}=30\right)$, reformas constitucionais $\left(x^{2}=27\right)$, desenvolvimento $\left(x^{2}=21\right)$ e empresário $\left(x^{2}=21\right)$. As expressões dessa classe tem como peculiaridade a centralidade da defesa do governo, através de parlamentares que possuíam condição de afinidade com o governo, não necessariamente sendo pertencente das fileiras do PSDB. 
Gráfico 3. Dendrograma de CHD dos Segmentos Textuais nos resumos de pronunciamentos dos Diários da Câmara, Diários do Senado e Diários do Congresso Nacional ("Emenda da Reeleição": jan/1995 a set/1997).

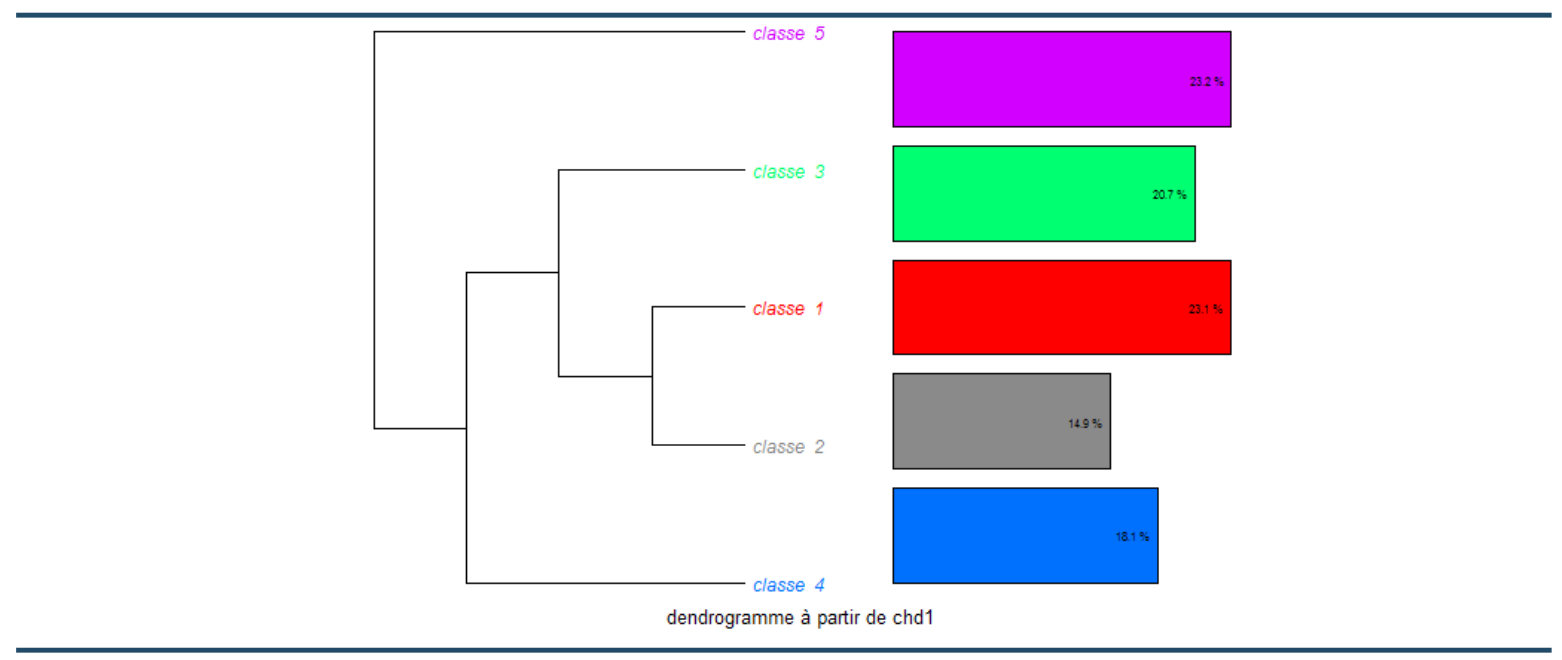

Fonte: Brasil (2016a, b).

Tabela 2. Formas associadas às classes produzidas na $\mathrm{CHD}$ nos resumos de pronunciamentos dos Diários da Câmara, Diários do Senado e Diários do Congresso Nacional ("Emenda da Reeleição": jan/1995 a set/1997).

\begin{tabular}{cccccccccc}
\hline Classe 1 & $x^{2}$ & Classe 2 & $x^{2}$ & Classe 3 & $x^{2}$ & Classe 4 & $x^{2}$ & Classe 5 & $x^{2}$ \\
\hline FHC & 231 & saúde & 132 & sessão & 397 & mandato & 1010 & artigo & 988 \\
\hline Governo & 141 & governo_federal & 83 & ordem & 171 & detentor & 953 & paragrafar & 639 \\
\hline Política & 132 & redução & 78 & presente & 169 & denunciar & 803 & permitir & 556 \\
\hline brasileiro & 97 & desemprego & 69 & homenagem & 107 & executivo & 744 & redação & 539 \\
\hline Reforma & 89 & recurso & 67 & presidência & 102 & apuração & 675 & primeiro_turn & 516 \\
\hline País & 81 & prorrogação & 66 & projeto & 98 & $\begin{array}{c}\text { compra_ } \\
\text { de_votos }\end{array}$ & 436 & substitutivo & 503 \\
\hline Tese & 71 & descaso & 63 & câmara & 91 & aprovação & 432 & PEC_1 & 457 \\
\hline $\begin{array}{c}\text { reeleição_do_ } \\
\text { presidente }\end{array}$ & 64 & região & 61 & dia & 82 & $\begin{array}{c}\text { venda_de_ } \\
\text { votos }\end{array}$ & 412 & novo & 439 \\
\hline $\begin{array}{c}\text { Nacional } \\
\text { privatização_ } \\
\text { da_Vale }\end{array}$ & 63 & tribunal & 61 & questão & 80 & reeleição & 358 & aprovar & 421 \\
\hline $\begin{array}{c}\text { Fonte:Elaboração do autor. } \\
\text { programa }\end{array}$ & 58 & mesa & 75 & CPI & 273 & cargo & 415 \\
\hline
\end{tabular}

Enquanto a Classe 1 apresenta-se como a de maior incidência sobre o conjunto dos resumos recolhidos, a classe mais próxima dela é também a menor de todas. A Classe 2 concentrou $14,9 \%$ dos segmentos textuais de todo o corpus. Apesar da quantidade inferior, trata-se de um importante bloco de expressões de conteúdo crítico ao Governo de FHC. Suas menções à saúde $\left(x^{2}=132\right)$, ao governo federal $\left(x^{2}=83\right)$, a redução $\left(x^{2}=78\right)$, a desemprego $\left(x^{2}=69\right)$ e a descaso $\left(x^{2}=63\right)$ são sinais das críticas desferidas sobretudo à situação da saúde pública e ao nível de desemprego na economia (que teve resultados anuais de incidência sobre 7,2\% da população ativa em 1996 e 8,2\% em 1997, segundo 
dados em IPEA, 2016). Discursos característicos dessa classe podem ser encontrados entre parlamentares da oposição.

A terceira classe discursiva remonta aos usos regimentais para fins políticos. Em relação aos avanços do governo na pauta do processo legislativo da Emenda da Reeleição, alguns parlamentares da oposição fizeram enfrentamento a essa questão por meio de pronunciamentos que visavam a denunciar e a protelar o processo decisório atinente à votação da matéria. Assim, a Classe 3 ocupou 20,7\% do total de pronunciamentos, com maior incidência entre os meses de agosto e dezembro de 1996, e teve como figura emblemática o deputado federal Chico Vigilante (PT-DF), notabilizado por reclamações de ausência de quórum para a votação e por ter rasgado o regimento interno da Câmara dos Deputados em uma sessão plenária (VOTAÇÃO..., 1996). Os segmentos textuais a ele identificados são espécies de instrumentos de batalha política da oposição baseada na disputa da "forma com que a Emenda da Reeleição tramitava" (mais à frente, ver-se-á a Classe 5, também detentora de expressões de batalha da oposição, mas vinculada ao "conteúdo da emenda"). Algumas formas léxicas que pontuaram e são relevantes nela, como sessão $\left(x^{2}=397\right)$, ordem $\left(x^{2}=171\right)$, projeto $\left(x^{2}=98\right)$, dia $\left(x^{2}=82\right)$, questão $\left(x^{2}=80\right)$ e mesa $\left(x^{2}=75\right)$.

A Classe 4 é o conjunto de segmentos textuais relativos ao estouro do escândalo da compra de votos para a aprovação da Emenda da Reeleição, representando 18,1\% do conjunto do corpus submetido ao computo estatístico. Esses pronunciamentos ocorreram principalmente no mês de maio de 1997 e foram espaços privilegiados para a propositura de uma CPI para investigar o caso, bem como para a simples denúncia (de resultado estéril, pois sem resultado efetivo) de prática de corrupção por parte do Governo de FHC. Dentre as principais formas léxicas estão mandato $\left(x^{2}=1.010\right)$, detentor $\left(x^{2}=953\right)$, denunciar $\left(x^{2}=803\right)$, apuração $\left(x^{2}=675\right)$, compra devotos $\left(x^{2}=436\right)$ e CPI $\left(x^{2}=273\right)$.

O último bloco de segmentos de textos classificados foi na Classe 5, que abrange 23,2\% do conjunto analisado. Trata-se da maior categoria analisada junto da Classe 1, tendo por elemento principal um conjunto de segmentos textuais oriundos de diversos partidos e parlamentares (com ligeira predominância dos discursos de parlamentares favoráveis à aprovação da Emenda da Reeleição) e situada principalmente em pronunciamentos expressos no mês de aprovação em primeiro turno da emenda na Câmara (em janeiro de 1997). Trata-se portanto de uma classe relevante para o processo decisório, com predominância associativa de formas léxicas relacionadas efetivamente a 
T\&P A linguagem e a agenda: uma análise de correspondência de discursos relacionados à Emenda da Reeleição (1995-1997)

ele, como artigo $\left(x^{2}=988\right)$, paragrafar $\left(x^{2}=639\right)$, o verbo permitir $\left(x^{2}=553\right)$, redação $\left(x^{2}=539\right)$, primeiro turno $\left(x^{2}=516\right)$ e substitutivo $\left(x^{2}=503\right)$.

Como a batalha pela aprovação da Emenda da Reeleição foi vencida pelo governo de maneira imperiosa na Câmara - apesar das tensões ocorridas junto dos adversários naquele janeiro de 1997 -, houve depósito de confiança da oposição na disputa de âmbito técnico-legislativa ocorrida na sequência da votação em primeiro turno. Isso fica revelado nos resultados expressados pela Classe 5: os segmentos textuais portadores dos maiores escores nessa classe são os relacionados às disputas em torno do conteúdo da emenda, daquilo que poderia ser feito de modificações nela por meio dos Destaques de Votação em Separado (DVS). Como os seus resultados são bastante significativos, é imprescindível entender como essa comunicação estritamente relacionada ao trâmite regimental teve impacto sobre o conjunto de todos os pronunciamentos relativo à Emenda da Reeleição no Congresso. Isso será melhor esclarecido a partir de agora, com a análise multivariada das cinco classes e as formas léxicas que as preenchem.

As relações entre as cinco classes irão indicar os fatores subjacentes que as colocam em correlação. Isso serve para a descoberta dos elementos que indicam a fusão delas e a consequente totalidade do que se disse sobre a Emenda da Reeleição no parlamento brasileiro - para se dispor em correlação aquilo que foi endogenamente conversado entre os agentes políticos responsáveis pela aprovação da matéria. Entra em cena novamente a análise fatorial feita por meio de uma disposição rotacional oblíqua (oblimin) dos fatores (FIELD, 2009, p. 568). A medida de adequação da amostra utilizada foi a Kaiser-Meyer-Olkin, KMO (PALANT, 2007 apud FIGUEIREDO FILHO; SILVA JÚNIOR, 2010), cujo valor aferido foi de 0,715 .

A manifestação de autovalor ${ }^{11}$ nas correlações entre as cinco classes permitiu a apreensão dos fatores intrínsecos, cada qual correspondendo a um percentual de abrangência. Os percentuais de cobertura indicaram quatro fatores, com a seleção do Fator 1, correspondendo a 38,3\%, e do Fator 2, relativo a 27,5\%, juntos correspondendo a $65,8 \%$ das relações estabelecidas entre classes e formas nos pronunciamentos que mencionaram a Emenda da Reeleição (exposto em Gráfico 4).

Pelo nível de significância do $x^{2}$ das formas ativas de cada classe, chegou-se à conclusão de que a análise fatorial deveria processar 534 formas (100\% das significantes),

11 Os resultados dos autovalores são: de 0,526 na correlação entre a Classe 5 e as Classes 1, 2, 3 e 4; de 0,377 para a Classe 4 em correlação às Classes 1, 2 e 3. 
75 na Classe 1 (14,0\%), 139 na Classe 2 (26,0\%), 118 na Classe 3 (22,0\%), 70 na Classe 4 $(13,1 \%)$ e 132 na Classe $5(24,9 \%)$.

A distribuição correlacional dos dados utilizados indica que o Fator 1 (na posição horizontal) diz respeito à clivagem existente entre as classes e formas de conteúdo prático para o processo legislativo da Emenda da Reeleição, em contraponto às menos eficazes. Pelo que se está disposto na análise, quanto maior a carga fatorial dele, menos operacional será o pronunciamento (a classe e a forma dele). Isso demonstra o destaque da efetividade dos pronunciamentos de janeiro de 1997: como pode ser visto na descrição da Classe 5, a "tropa de choque" do governo atuou para aprovar a PEC 01/1995, e as suas áridas instruções discursivas foram as vencedoras no processo. Tais discursos diferenciaram-se radicalmente dos demais, principalmente dos situados nas classes 1, 2 e 4, portadores de discursos menos marcados por formas exigidas para a orientação de votos aos parlamentares no processo legislativo. A Classe 3 ficou em uma posição intermediária, com discursos menos operacionais, todavia reclamantes de

Gráfico 4. AFC (correlação entre formas e Classes). Resumos de pronunciamentos dos Diários da Câmara, Diários do Senado e Diários do Congresso Nacional ("Emenda da Reeleição": jan/1995 a set/1997).

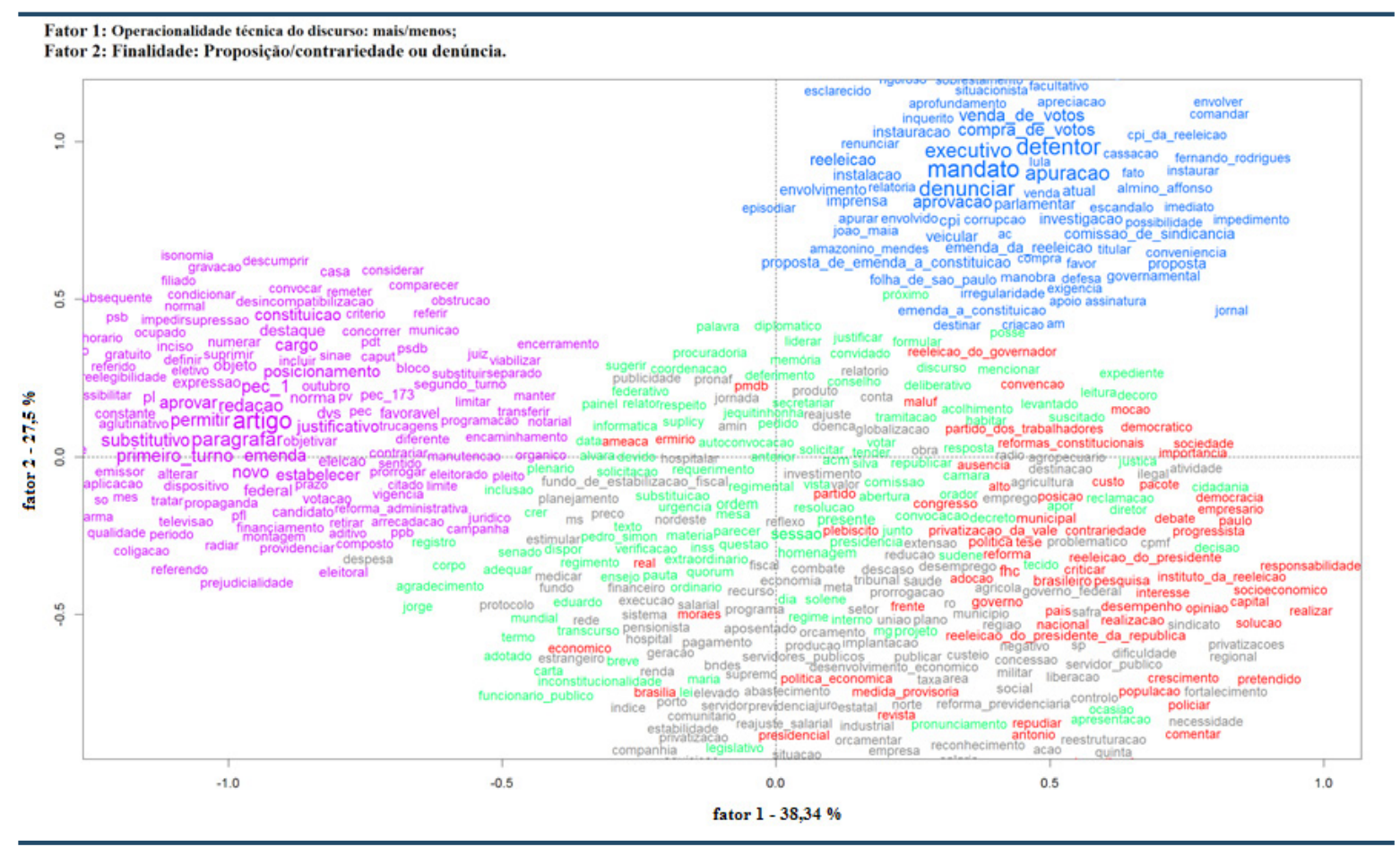

Fonte: Brasil (2016a, b). 
T\&P A linguagem e a agenda: uma análise de correspondência de discursos relacionados à Emenda da Reeleição (1995-1997)

como o processo legislativo deveria tramitar - trata-se das formas protelatórias utilizadas principalmente pela oposição, na busca de atrasar o processo legislativo da matéria.

Já a segunda categoria diz respeito à finalidade da classe e da forma utilizada no pronunciamento pelo parlamentar. Nesse sentido, as cargas mais altas do Fator 2 estão preenchidas por discursos com conteúdo de denúncia, enquanto os que possuem carga negativada nele são de temas mais propositivos e, quando de maior teor crítico, estão abordando questões voltadas para as políticas públicas do Governo de FHC. As cargas de denúncia estão situadas nos segmentos textuais da Classe 4, oriundos principalmente do mês de maio de 1997 e com formas relacionadas ao caso da compra de votos. Algumas formas da Classe 5 também possuem esse viés, sendo elas alvo de grande controvérsia na aprovação da Emenda da Reeleição, tais como as opiniões sobre a desincompatibilização (o afastamento do cargo) daqueles que iriam disputar a reeleição - esse foi um assunto vencido por FHC, que defendia a não desincompatibilização -, a defesa do princípio de isonomia na disputa eleitoral e a forma obstrução, relativa à postura da maioria dos opositores da emenda na votação em primeiro turno na Câmara. Entre as cargas negativadas para esse fator encontram-se as classes 1 e 2, com suas formas voltadas para questões menos diretamente relacionadas à Emenda da Reeleição. A segunda classe teve formas como juro, reforma da previdência e reconhecimento entre as de carga mais negativada, enquanto a primeira notabilizou-se por política econômica, crescimento econômico e pretendido.

Vale destacar a presença de uma forma solitária, um pouco distante do núcleo de sua classe preponderante (a Classe 1), porém de modo a estar aproximado da ponta do fator que atesta operacionalidade institucional: a forma real, proveniente do nome da moeda brasileira. Sua posição indica que há uma grande dispersão em várias formas das classes 1 e 2, de modo que vários de seus termos possuem alguma afinidade ideológica com a agenda do governo, figurando entre as que orbitam em torno da Classe 5 (mais atrelada ao processo legislativo da Emenda da Reeleição em si). Formas como planejamento, Fundo de Estabilização Fiscal, Econômico (advindo do Banco Econômico), financeiro e publicidade são termos que pertencem às classes 1 e 2, todavia circundam a extremidade esquerda do Fator 1 como se fosse um arco protetivo a contornar o processo de aprovação da Emenda da Reeleição.

Por fim, percebe-se que por mais que não tenham conseguido pautar a agenda governamental de FHC (a história nos prova a vitória da "obsessão pela estabilidade"), 
os termos da Classe 2 lograram o êxito não conquistado pela Classe 4 (ambas marcadas por pronunciamentos de oposicionistas ao governo). Por que isso ocorreu? O motivo pode ser percebido na presença de várias reivindicações propositivas na Classe 2, algo ausente na Classe 4. Por mais que divergissem do governo, as críticas por serviços públicos e por saúde pública (duas formas associadas à Classe 2) alimentavam-se também da necessidade de o governo firmar acordos com parlamentares de todos os recantos do país, e grande parte desses pleitos era feita por parlamentares de estados do norte e do nordeste. Desse modo, apesar de ser criticado pelos autores desses discursos, o governo agia no sentido de buscar percepção política da demanda. O governo de FHC não foi um governo isolado nesse sentido, pois conseguiu estabelecer diálogo com forças políticas advindas dos grotões do país. Contraditoriamente, essas alianças que possibilitaram que os discursos da Classe 2 tivessem alguma eficácia foram também os que alimentaram os atos que produziram a revolta presente na Classe 4. Essa revolta não conseguiu o mínimo de resultado: a CPI não foi instalada, e o escândalo da compra de votos não passou de discurso denuncista dos jornais e de bravatas estéreis dos parlamentares de oposição contra o governo.

\section{Considerações finais}

Na análise exógena dos comportamentos políticos expressos nas colunas Painel, a oposição à esquerda ao Governo de FHC que tangenciou temporalmente o processo legislativo da Emenda da Reeleição sobressaiu-se em questões relacionadas aos direitos humanos. No caso endógeno, os discursos dos parlamentares de oposição destacaram-se pelo caráter de denúncia sobre a compra de votos no primeiro turno da PEC 01/1995. Ambos foram abordagens políticas dispersas da agenda política do Governo de FHC e do eixo decisório de aprovação da Emenda da Reeleição. A primeira pauta se deu por meio de uma mobilização de viés anti-institucional - movida principalmente pelo MST -, enquanto a segunda deu-se num âmbito oposto, estritamente legislativo.

De certa forma, mobilização anti-institucional por parte de uma oposição organizada em movimentos sociais possui algum potencial de pauta da política. Todavia, essa grande concentração de forças em mobilização revela-se dispersa do centro decisório do governo, limitando-se a uma modalidade política de exercício de pressões externas sobre FHC e com baixa capacidade de pauta de matérias legislativas (como foi no caso 
T\&P A linguagem e a agenda: uma análise de correspondência de discursos relacionados à Emenda da Reeleição (1995-1997)

da Emenda da Reeleição). A não existência de pontes de negociação institucional com o governo fez com que esse tipo de mobilização ficasse presa em si mesma, sem a capacidade de pautar outros assuntos. O descolamento entre os temas de oposição "das ruas" $"$ "do Congresso" a FHC pode ser visto no modo como a coluna Painel retratou acentuadamente as negociações de bastidores a respeito da luta pela terra, porém negligenciou o tema da compra de votos entre os mais citados (tema de maior relevo para a oposição legislativa). Há também nisso um sinal de que a proposta de CPI da compra de votos não fora capaz de agitar o governo, tal como ocorreu no caso da pauta anti-institucional.

Há no conjunto desses elementos não somente a expressão de uma fragmentação de mobilização política das oposições ao Governo de FHC (grandiosa nas ruas e antipáticas às instituições; outra de pauta limitada à mirrada deliberação ineficaz no parlamento), mas também a incapacidade de conseguir influenciar os rumos do ponto fundamental da agenda de FHC: as reformas que tocavam na economia - algo indiretamente expresso pela literatura (ARAGÃO, 1996; COUTO; ABRÚCIO, 1999; COUTO; ARANTES, 2002; COSTA, 2002; IANONI, 2009; LOUREIRO; ABRÚCIO, 2002; MELO, 2002). Pode-se perceber uma coincidência - algo que necessita de maiores investigações para depreender correlações ou causalidade - entre a ineficácia decisória e de negociação da oposição na pauta da agenda e o fato de o governo FHC tender para a formação de alianças de governo caracterizadas pela coalizão de centro-direita que predominou naquele período.

Parte do Governo de FHC administrou a condição dispersa dessa oposição ineficaz e atraiu para o centro decisório aqueles que podiam ser seduzidos pela imperiosidade do poder executivo no sistema de governo brasileiro no período e pela força simbólica da retórica da estabilidade (a associação entre estabilidade política e econômica, discurso apelativo para persuadir opinião pública e forças políticas no congresso). Estiveram expressas nisso as negociações para o governo "ganhar" o PMDB e o PPB. Isso possibilitou a realização de algumas propostas da agenda política. A emenda da reeleição esteve correlacionada a esses acontecimentos e às respectivas associações de linguagem neles expressos. 


\section{Referências}

ANDERSON, P. Balanço do neoliberalismo. In: SADER, E.; GENTILI, P. (Ed.). Pós-neoliberalismo: as políticas sociais e o estado democrático. Rio de Janeiro: Paz e terra, 1995. p. 9-23.

ARAGÃO, M. A ação dos grupos de pressão nos processos constitucionais recentes no Brasil. Revista de Sociologia e Politica, v. 6, n. 7, p. 149-165, 1996.

BARBETTA, P. A. Estatística aplicada às ciências sociais. Florianópolis: Ed. UFSC, 2011.

BELLUZZO, L. G.; ALMEIDA, J. G. Depois da queda: a economia brasileira da crise da dívida aos impasses do Real. São Paulo: Civilização Brasileira, 2002.

BRASIL. Constituição da República Federativa do Brasil. Diário Oficial [da] República Federativa do Brasil, Brasília, DF, 5 out. 1988.

BRASIL. Câmara dos Deputados. Diários da Câmara dos Deputados. Brasília, 2016a. Disponível em: <http://www.camara.leg.br/sileg>. Acesso em: 8 jun. 2016.

BRASIL. Senado Federal. Diários do Senado Federal. Brasília, 2016b. Disponível em: <http://www. legis.senado.gov.br/diarios/Diario>. Acesso em: 8 jun. 2016.

CAMARGO, B. V.; JUSTO, A. M. Iramuteq: um software gratuito para análise de dados textuais. Temas em Psicologia, v. 21, n. 2, p. 513-518, 2013.

COLUNAS Painel. Folha de S.Paulo, São Paulo, 1 jan. 1995 a 30 set. 1997. Chave de busca:"Emenda da Reeleição".

CONSTITUIÇÃO é inflacionária e precisa sofrer alterações diz Ibrahim Eris. Folha de S. Paulo, São Paulo, 24 dez. 1990.

COSTA, V. M. F. A dinâmica institucional da reforma do Estado: um balanço do período FHC. In: ABRÚCIO, F.; LOUREIRO, M. R. (Ed.). O Estado numa era de reformas: os anos FHC. Parte 2. Brasília: MP Seges, 2002. p. 9-56

COUTO, C. G.; ABRÚCIO, F. L. Arenas políticas e agenda econômica: os caminhos institucionais do Real. In: ENCONTRO ANUAL DA ANPOCS, 23., 1999, Caxambu. Anais... São Paulo: Anpocs, 1999.

COUTO, C. G.; ARANTES, R. B. Constituição ou Políticas Públicas? Uma avaliação dos anos FHC. In: ABRÚCIO, F.; LOUREIRO, M. R. (Ed.). O Estado numa era de reformas: os anos FHC. Parte 1. Brasília: MP Seges, 2002. p. 75-120.

EASTON, D. Categorias para análise de sistemas em política. In: EASTON, D. (Ed.). Modalidades de Análise Política. Rio de Janeiro: Zahar, 1970. p. 185-199.

EMPRESÁRIOS do comércio acham Carta inflacionária. Folha de S. Paulo, São Paulo, 7 out. 1988.

FIELD, A. Descobrindo a estatística usando o SPSS. Porto Alegre: Artmed, 2009.

FIGUEIREDO FILHO, D. B.; SILVA JÚNIOR, J. A. Visão além do alcance: uma introdução à análise fatorial. Opinião Pública, v. 16, n. 1, p. 160-185, 2010. 
T\&P A linguagem e a agenda: uma análise de correspondência de discursos relacionados à Emenda da Reeleição (1995-1997)

IANONI, M. Políticas Públicas e Estado: o Plano Real. Lua Nova, v. 78, p. 143-183, 2009.

INSTITUTO DE PESQUISA ECONÔMICA APLICADA - IPEA. Brasília, 2016. Disponível em: <http:// www.ipeadata.gov.br>. Acesso em: 8 jun. 2016.

LOUREIRO, M. R.; ABRÚCIO, F. L. 2002. Incrementalismo, Negociação e Accountability: análise das reformas fiscais no Brasil. In: ABRÚCIO, F.; LOUREIRO, M. R. (Ed.). O Estado numa era de reformas: os anos FHC. Parte 2. Brasília: MP Seges, 2002. p. 57-102.

LUHMANN, N. Introdução à teoria dos sistemas. Petrópolis: Vozes, 2011.

MATURANA, H. R.; VARELA, F. A Árvore do Conhecimento: as bases biológicas do entendimento humano. Campinas: Editorial Psy, 1995.

MELO, M. A. Reformas constitucionais no Brasil: instituições políticas e processo decisório. Rio de Janeiro: Revan, 2002.

MIRANDA, V. G. Âncoras monetárias e ordem atômica: a aprovação da emenda da reeleição no Brasil. 2015. Tese (Doutorado)-Faculdade de Ciências Humanas, Universidade Federal da Grande Dourados, Dourados, 2015.

MOTTA, S. "Tem de mudar": entrevista. Veja, São Paulo, 23 jul. 1997.

NASCIMENTO, A. R. A.; MENANDRO, P. R. M. Análise lexical e análise de conteúdo: uma proposta de utilização conjugada. Estudos e Pesquisas em Psicologia, v. 6, n. 2, p. 72-88, 2006.

POULANTZAS, N. O Estado, o poder, o socialismo. Rio de Janeiro: Graal, 1980.

SALONE, J. J. Analyse textuelle avec IRaMuTeQ et interpretations référentielles des programes officiels de mathématique en quatrième. Sciences-Croisées, v. 13, p. 1-13, 2013.

VOTAÇÃO da emenda acaba em tumulto Deputado do PT rasga regimento. Folha de S.Paulo, São Paulo, 5 nov. 1996.

Recebido: 08 jun., 2016

Aceito: 24 jan., 2017 